\title{
Myasthenia gravis - diagnostikk og behandling
}

\author{
Omkring 700 personer i Norge har myasthenia gravis, en autoimmun \\ sykdom som rammer nevromuskulær transmisjon og gir fluktuerende \\ svakhet i enkelte muskler som eneste symptom. Diagnosen er basert \\ på typiske symptomer og funn, påviste antistoffer og nevrofysiologisk \\ unders $\varnothing$ kelse. Symptomatisk behandling med acetylkolinesterasehem- \\ mer er vanligvis effektivt, men de fleste trenger i tillegg immunsup- \\ pressiv medikamentell behandling. Antigenspesifikk behandling testes \\ i eksperimentelle sykdomsmodeller.
}

Myasthenia gravis er en autoimmun sykdom som selektivt affiserer transmisjonen fra motorisk nerve til tverrstripet muskel (fig 1). Svakhet i tverrstripet muskulatur er dermed eneste sykdomsmanifestasjon. Svakheten har typisk en komponent av muskeltretthet, og den blir mest fremtredende etter gjentatt og langvarig muskelbruk. Døgnvariasjon er typisk - symptomene kan for eksempel være fraværende om morgenen, men tydelige om kvelden (1-3).

Hjernenerveinnerverte muskler rammes ofte. Dobbeltsyn, ptose og svakhet i mimiske muskler samt tale- og svelgevansker er typisk (1-3). Nakkemusklene er ofte svake, likeledes proksimale ekstremitetsmuskler. Respirasjonssvikt er den store trusselen. Glatt muskulatur og hjertemuskel påvirkes ikke ved myasthenia gravis. Muskelsvakheten er vanligvis symmetrisk, med unntak av øyemuskelparese, som ofte er påfallende asymmetrisk. Myasthenia gravis med MuSK-antistoffer er gjerne noe mer alvorlig, har mindre fluktuasjon og kan gi lett muskelatrofi (4).

Myasthenia gravis har en prevalens på 150 per million, med en årlig insidens på 10 per million (5-7). Hos de fleste skjer sykdomsdebuten etter fylte 50 år. I den eldre aldersgruppen er det noen flere menn enn kvinner. Hos dem med debut før 50 års alder er det en klar overvekt av kvinner. Myasthenia gravis opptrer også hos barn, som en juvenil form (8). Demografisk endring og god behandling av sykdommen, med upåvirket livslengde, har medført at eldre pasienter nå er i flertall $(5-7,9)$. Det er en viss geografisk variasjon i forekomst - juvenil myasthenia gravis er vanligst i Øst-Asia og myasteni med MuSK-antistoffer er vanligst i middelhavsområdet.

I denne artikkelen gjennomgår vi diagnostikk og behandling av myasthenia gravis. Artikkelen er basert på søk i Web of Science, Cochrane-databasen og konsensus på grunnlag av egne erfaringer i Nasjonal nevromuskulær interessegruppe.

\section{Diagnose}

Viktigste forutsetning for å stille diagnosen er å tenke på muligheten av myasthenia gravis. Det kliniske sykdomsbildet er gjerne typisk. Hos yngre pasienter kan symptomene mistolkes som uspesifikk tretthetstilstand eller psykisk sykdom. Det er viktig å få frem at det dreier seg om konkrete pareser og objektiv muskelsvakhet, men vanligvis med vesentlig fluktuasjon. Hos eldre kan ptose representere en særlig differensialdiagnostisk utfordring. Symptomene kan blant annet misoppfattes som hjernestammesykdom, for eksempel hjerneslag i bakre kretsløp. Variasjon i løpet av dagen og sideforskjell av ptose taler for myasthenia gravis.

Hos $70-80 \%$ av pasientene med myasthenia gravis blir det påvist antistoffer mot acetylkolinreseptor i serum (1-3). Ytterligere noen har antistoffer mot muskelspesifikk kinase (MuSK). Hos pasienter med myasthenia gravis og rent okulære symptomer har bare omkring halvparten påvisbare antistoffer, og da alltid mot acetylkolinreseptor (10). Måling av antistoffer mot acetylkolinreseptor skal utføres hos alle der det er klinisk mistanke om sykdommen. MuSKantistoffer undersøkes hos dem med negativ test for acetylkolinreseptorantistoffer og fortsatt berettiget mistanke om myasthenia gravis. Responstid for laboratoriet kan være inntil tre uker for antistoffer mot acetylkolinreseptor og inntil fire uker for MuSK. Klart positivt prøvesvar anses i klinisk praksis å være nær $100 \%$ spesifikt for myasthenia gravis. Den lave risikoen for falskt positiv svar innebærer at man kan ha en svært lav terskel for å ta prøven. En pasient med typiske symptomer og påviste antistoffer har sikker myasthenia gravis.

Nevrofysiologisk testing med repetitiv nervestimulering og enkeltfiberelektromyografi (SF-EMG) representerer funksjonelle undersøkelser av nevromuskulær transmisjon. De gir umiddelbart svar, men de er teknisk krevende og det trengs særlig eksper-

\author{
Nils Erik Gilhus \\ nils.gilhus@uib.no \\ Klinisk institutt 1 \\ Universitetet i Bergen \\ og \\ Nevrologisk avdeling \\ Haukeland universitetssykehus \\ Emilia Kerty \\ Nevrologisk avdeling \\ Oslo universitetssykehus \\ og \\ Klinisk institutt \\ Universitetet i Oslo \\ Sissel Løseth \\ Nevro, hud- og revmatologisk avdeling \\ Universitetssykehuset Nord-Norge \\ og \\ Institutt for klinisk medisin \\ Universitetet i Troms $\emptyset$ - Norges arktiske \\ universitet
}

\section{Åse Mygland}

Klinisk institutt 1

Universitetet i Bergen

og

Nevrologisk avdeling

Sørlandet sykehus

og

Avdeling for rehabilitering

Sørlandet sykehus

Chantal Tallaksen

Nevrologisk avdeling

Oslo universitetssykehus

Klinisk institutt

Universitetet i Oslo

\section{HOVEDBUDSKAP}

Spesifikke muskelantistoffer sikrer diagnosen med nær $100 \%$ spesifisitet og $80 \%$ sensitivitet

Subgruppeinndeling basert på biomarkører lalder ved debut, symptomutbredelse, antistoffer, thymuspatologil er førende for behandlingsvalget

Kjernen i den medikamentelle behandlingen er acetylkolinesterasehemmer og immunsuppresjon

Truende myasten krise med økt respirasjonsbesvær skal behandles akutt og intensivt, med intravenøst immunglobulin eller plasmautskiftning

Forutsatt optimal behandling er prognosen ved myasthenia gravis god 


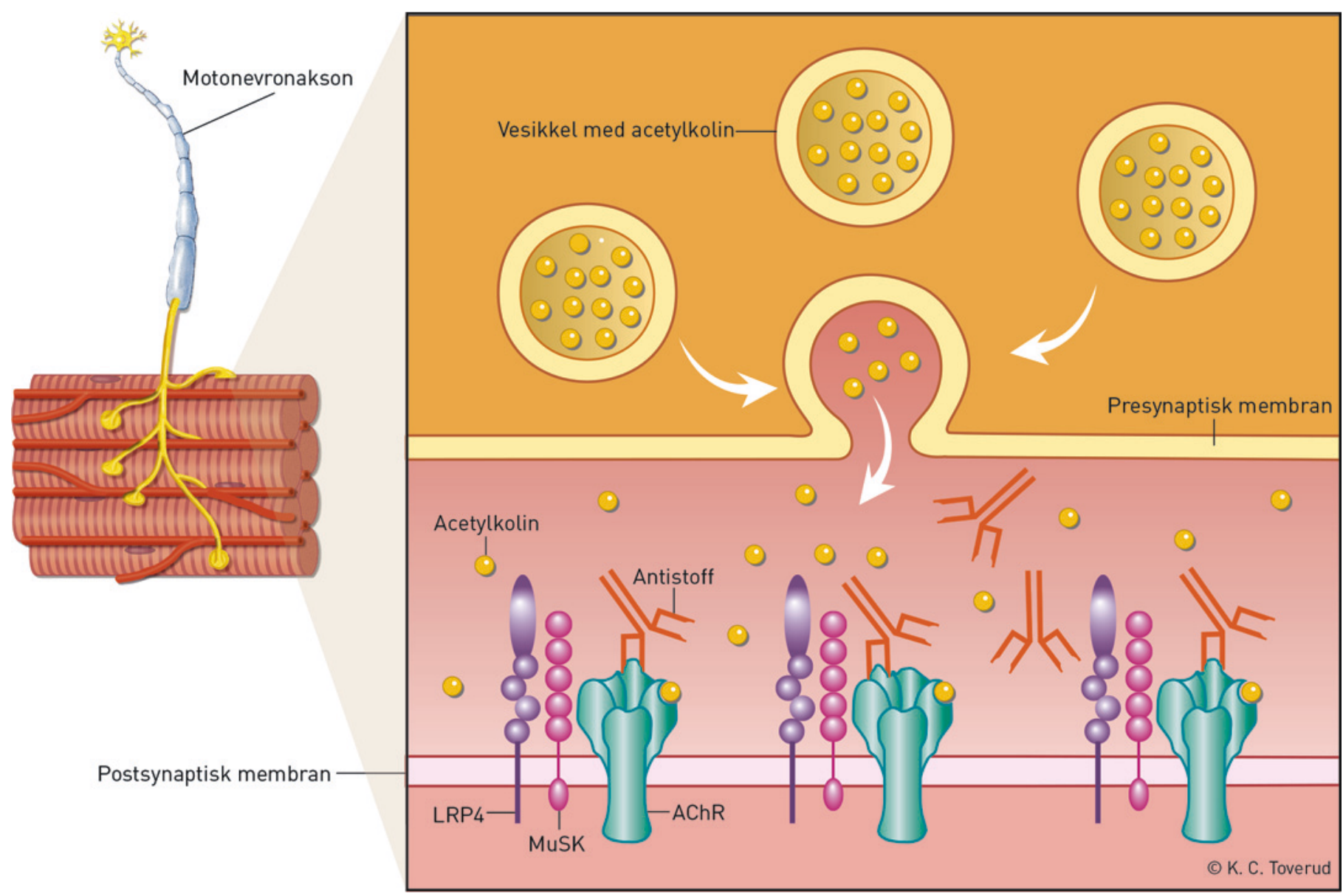

Figur 1 Acetylkolin frigjøres presynaptisk som respons på et aksjonspotensial i motonevronet. Ved binding av acetylkolinet til acetylkolinreseptorer (AChR) postsynaptisk genereres muskelkontraksjon. Ved myasthenia gravis binder antistoffer til AChR, eller i sjeldne tilfeller til proteinene MuSK og LRP4, som er nødvendige for funksjonen til AChR. Slik antistoffbinding medfører redusert antall og svekket funksjon av AChR, og dermed muskelsvakhet

tise. Enkeltfiber-EMG er den mest sensitive undersøkelsen, men patologiske funn er ikke spesifikke for myasthenia gravis. Nervemuskel-transmisjonen er selektivt hemmet, og nevrofysiologisk undersøkelse avspeiler dette. Ved myasthenia gravis uten påvisbare antistoffer vil nevrofysiologisk undersøkelse som regel vise funn som er så karakteristiske at de bekrefter nevromuskulær transmisjonssykdom og sannsynliggjør diagnosen (fig 2) $(1-3,11)$. Det er avgjørende at de affiserte musklene testes, også ansiktsmuskler og bulbære muskler.

Hvordan symptomer og funn responderer på acetylkolinesterasehemmer har diagnostisk verdi. Vesentlig bedring er typisk for myasthenia gravis. Tidligere benyttet man gjerne intravenøs testing med edrofonium. Med gode antistoffanalyser og nevrofysiologisk testing tilgjengelig gjøres dette sjeldnere enn før, men særlig ved rent okulære symptomer og funn kan det være nyttig. Effekten av noen dagers peroral behandling med pyridostigmin er verdt å registrere diagnostisk. Bedring av muskelstyrke ved nedkjøling (ice-pack test) har sensitivitet og spesifisitet som kan gjøre den nyttig ved ptose.

Vel $10 \%$ av pasientene med myasthenia gravis har et tymom. Det skal derfor gjøres CT- eller MR-undersøkelse av mediastinum hos alle pasienter. Hos dem uten tymom er thymushyperplasi vanlig og kan ses som en forstørret kjertel ved bildeundersøkelse. Verken sensitivitet eller spesifisitet for tymom ved CT- og MR-undersøkelse er fullgod. Tilstedeværelse av antistoffer mot titin i tillegg til antistoffene mot acetylkolinereseptor vil hos yngre pasienter gi sterk mistanke om tymom (12). Pasienter uten antistoffer mot titin har svært sjelden tymom.

\section{Komorbiditet}

Komorbiditet skal alltid klarlegges presist og vil ha betydning både for symptombilde, behandlingsrespons og behandlingsmål (13). Særlig hos eldre med tretthet, tung pust eller nedsatt allmenntilstand kan det være vanskelig å avgjøre i hvilken grad symptomene skyldes hjerte- og lungesykdom, andre sykdommer eller alder.

Det er vesentlig at ikke andre sykdommer underbehandles eller overses fordi man feilaktig tilskriver plagene myasthenia gravis.

\section{Subgrupper}

Patogenese, behandlingsrespons og prognose avhenger i stor grad av myasthenia gravis-subgruppe (1-3). Korrekt subgruppediagnostikk er dermed viktig (ramme 1). Det er patogenetisk overlapping mellom myasthenia gravis med debut før og etter 50 års alder. En noe eldre pasient med thymushyperplasi hører egentlig hjemme i tidligdebutgruppen. Det er markante ulikheter i HLA (vevstypeantigen)-assosiasjonen mellom subgruppene $(14,15)$.

Hos subgruppen med tymom er myasthenia gravis en paraneoplastisk tilstand. Omkring en tredel av alle med tymom får myasthenia gravis med antistoffer mot acetylkolinreseptor. Tymom kan være assosiert med flere andre autoimmune sykdommer, men veldig mye sjeldnere enn for myasteni. Det er viktig å behandle både muskelsvakheten og tymomet. Behandlingsresponsen er ofte litt dårligere i denne subgruppen.

Myasthenia gravis debuterer ofte med 
øyesymptomer og kan fremtre som rent okulær i tidlig fase. Dersom pasienten etter to år fortsatt kun har okulære symptomer, er det mest sannsynlig at sykdommen forblir okulær, selv om generalisering med alvorlige symptomer kan skje også etter lang tid (10).

Antistoffer mot acetylkolinereseptor, MuSK og lipoproteinrelatert protein 4 (LRP4) finnes omtrent aldri samtidig. Pasientene har enten det ene eller det andre. Det er kliniske gruppeforskjeller mellom pasientene, men ikke så fremtredende at undergruppene kan diagnostiseres klinisk. Mens MuSKmyasteni er noe mer alvorlig, tenderer LRP4myasteni til å være lettere $(1-3,16)$. Det kan foreløpig ikke undersøkes for LRP4-antistoff i klinisk praksis (3).

Gruppen pasienter uten påvisbare antistoffer er heterogen. Enkelte har antistoffer med så lav affinitet at de ikke identifiseres ved rutinetester, bare ved ikke-kommersielle cellebaserte teknikker (16). Slike pasienter hører egentlig til i en av de andre subgruppene. De øvrige kan sannsynligvis ha antistoffer mot andre molekyler i postsynaptisk membran som påvirker den nevromuskulære transmisjonen $(2,3)$. Noen kan sannsynligvis også ha sykdom som ikke er mediert av antistoffer. For pasienter der antistoffer ikke kan påvises, er det alltid grunn til å revurdere diagnosen. Dette gjelder særlig ved dårlig behandlingsrespons eller uventet utvikling med atypisk klinisk bilde.

\section{Behandling}

Når diagnosen er etablert, styres behandlingsintensiteten ut fra klinisk bilde. Gjentatte målinger av acetylkolinereseptorantistoff kan være en indikator på sykdomsutviklingen og kontrolleres ved usikker diagnose, generalisering av okulær myasthenia gravis, vesentlig symptomforverring eller vesentlig symptombedring (17). Fallende konsentrasjon peker vanligvis i retning av lavere sykdomsintensitet.

Repetitiv nervestimulering med vurdering av motorisk amplitude kan hjelpe i bedømmelsen av dose-respons-forhold for behandling med acetylkolinesterasehemmer (11).

Symptomatisk medikamentell behandling Førstevalgsbehandlingen ved myasthenia gravis er medikamenter som øker tilgjengelig mengde acetylkolin i synapsen $(1-3,18)$. I praksis gis acetylkolinesterasehemmeren pyridostigmin. God effekt bekrefter diagnosen. Dosen bestemmes ut fra effekt og bivirkninger, først og fremst gastrointestinale. Acetylkolinesterasehemmere øker nemlig tilgjengelig acetylkolin også i det parasympatiske nervesystem.

Pasientene kan selv justere optimal dose etter behov, gjerne innenfor rammer (minimum og maksimum) satt av lege. Standard enkeltdose er $60 \mathrm{mg}$, men den kan reduseres ved bivirkninger med bruk av tabletter på 10 mg. Vanligvis doseres 2-4 ganger daglig. Myasthenia gravis med MuSK-antistoffer har vanligvis den dårligste effekten av acetylkolinesterasehemmer (4). For denne gruppen kan man forsøke 3,4-diaminopyridin, som øker frigjøringen av acetylkolin presynaptisk.

\section{Immunsuppressiv}

\section{medikamentell behandling}

Ved symptomer av betydning til tross for symptomatisk behandling skal immunsuppresjon settes i gang. Hos de aller fleste er kombinasjonen av prednisolon og azatioprin førstevalg $(1-3,18)$. Prednisolon gis vanligvis hver annen morgen og i gradvis økende dose for å redusere bivirkningene. Azatioprineffekten kommer først etter flere måneder.

I oppstartsfasen skal hematologiske prøver og leverfunksjon følges tett. Et moderat fall $\mathrm{i}$ antall leukocytter er vanlig og antagelig ønsket. Konsentrasjonen av leverenzymer i serum vil vanligvis øke, og opptil en tredobling indiserer ikke seponering av medikamentet og er ofte forbigående. Azatioprin har knapt nok negative langtidseffekter (19). Mangel på enzymet tiopurinmetyltransferase medfører som regel azatioprinbivirkninger, men det kan testes på dette før behandlingsstart (3). Med god kontroll på myastenisymptomene kan dosen av prednisolon og azatioprin reduseres. Det anbefales å opprettholde en lav dose i årevis, ofte livslangt, for å hindre residiv $(1-3,18)$.

Debut av myasthenia gravis etter 50 års alder, tilstedeværelse av tymom og antistoffer mot titin eller MuSK taler for langvarig og kanskje livslang immunsuppresjon. Utvikling i konsentrasjonen av acetylkolinreseptorantistoff er ikke etablert som prognostisk markør, men markert fall i konsentrasjonen anses likevel som gunstig (17).

Det er holdepunkter for at immunsuppressiv behandling ved okulær myasthenia gravis reduserer risikoen for generalisering av symptomene (10). For denne subgruppen kan en liten dose prednisolon være tilstrekkelig.

Dersom kombinasjonen av prednisolon og azatioprin ikke gir tilstrekkelig symptomkontroll, eventuelt fører til bivirkninger av betydning, anbefaler vi mykofenolatmofetil til pasienter med lette til moderate symptomer $(1-3,18,20)$. Velkontrollerte studier mangler for nesten alle terapialternativer ved myasthenia gravis. Anbefalingene bygger på kontrollerte studier av lavere kvalitet, samlematerialer og konsensusrapporter.

For myasthenia gravis med alvorlige symptomer anbefaler vi rituksimab som

\section{RAMME 1}

\section{Subgrupper av myasthenia gravis}

Gruppe I: Myasthenia gravis med debut før 50 år. Thymushyperplasi. Kvinneovervekt. Acetylkolinreseptorantistoff. lkke titinantistoff

Gruppe II: Mysthenia gravis med debut etter 50 år. Thymusatrofi. Nokså lik kjønnsfordeling. Acetylkolinreseptorantistoff. Titinantistoff kan være til stede

Gruppe III: Myasthenia gravis med tymom. $10-15 \%$ av alle. Debut i alle aldre, vanligst hos eldre. Acetylkolinreseptorantistoff. Titinantistoff hos $>95 \%$

Gruppe IV: Okulær myasthenia gravis. Symptomer og tegn utelukkende fra øyemusklene (diplopi, ptose). Med eller uten acetylkolinreseptorantistoff

Gruppe V: Myasthenia gravis med MuSKantistoff. Ikke acetylkolinreseptorantistoff. $1-5 \%$ av alle

Gruppe VI: Myasthenia gravis med LRP4antistoff. Ikke acetylkolinreseptorantistoff. $1-2 \%$ av alle

Gruppe VII: Myasthenia gravis uten påvisbare antistoffer. Heterogen gruppe.

annenlinjebehandling $(3,21,22)$. Dette monoklonale antistoffet binder selektivt til CD20-molekylet på B-lymfocytter. Teoretisk er det dermed velegnet for antistoffmedierte sykdommer. En rekke rapporter indikerer at omkring $80 \%$ av pasientene med myasthenia gravis oppnår tilfredsstillende behandlingsrespons, men randomiserte studier finnes ikke (22). Responsraten gjelder gjennomgående pasienter som ikke har hatt tilstrekkelig virkning av førstelinjeimmunbehandling med prednisolon og azatioprin, svært ofte har de også forsøkt ytterligere immundempende midler.

Effekten er særlig god hos pasienter med MuSK-antistoffer. Nettopp denne gruppen responderer ofte dårligere på annen terapi og har spontant et alvorligere forløp. Rituksimab doseres som ved revmatisk sykdom. Ofte ser én behandlingsserie ut til å være tilstrekkelig ved myasthenia gravis. Behandlingen gjentas imidlertid ved behov. Optimal tilpasning til annen immunsuppressiv behandling er dårlig dokumentert, men en kombinasjon med prednisolon og azatioprin er vanlig.

Erfaringene med bruk av rituksimab for myasthenia gravis hos en håndfull pasienter i Norge er så langt vi kjenner til svært gode. Bruken av medikamentet er nok økende, 


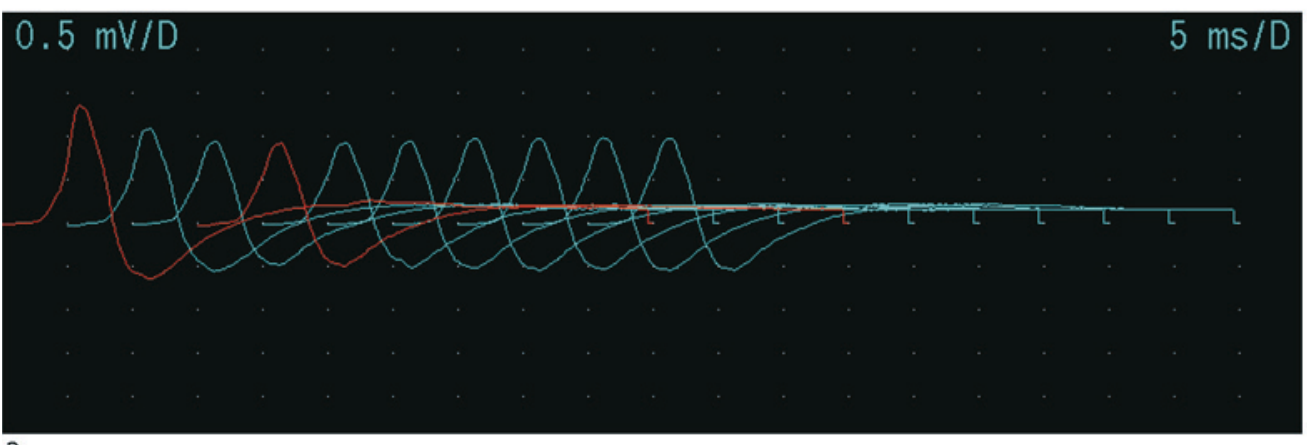

Figur 2 a) Repetitiv nervestimulering. Registrerende elektrode plasseres over muskelen (ved myasteni er proksimal muskel mest sensitiv) og tilførende nerve stimuleres med gjentatte elektriske stimuli. Her er det gitt ti stimuli med frekvens $3 \mathrm{~Hz}$. Normalt skal hver stimulus gi samme motoriske amplitude. Ved myasteni minker amplituden (dekrement) Det maksimale dekrement måles mellom 1.og 4. stimuli (her $32 \%$ ). Testen utføres både i hvile, rett etter at pasienten har kontrahert maksimalt, deretter gjentas den flere ganger, for eksempel ett, tre og fem minutter etter aktivering. b) Enkeltfiberelektromyografi (SF-EMG). EMG-nålen plasseres slik at man får registrert potensialer fra to muskelfibre tilhørende samme motoriske enhet. Muskelfibrene vil depolariseres omtrent samtidig. Ved myasteni vil tidsforskjellen i depolarisering mellom potensial 1 og potensial 2 variere (økt dirring). Noen potensialer blir blokkert (pil) og muskulaturen blir svak. Normal SF-EMG i klinisk svak muskulatur utelukker nærmest diagnosen myasteni men samtidig avventer man resultatet av pågående kontrollerte behandlingsstudier. Bekymringen for rituksimab er særlig knyttet til risiko for alvorlige bivirkninger. Progredierende multifokal leukoencefalopati (PML) er foreløpig ikke rapportert ved myasthenia gravis, men hos rituksimabbehandlede pasienter med andre sykdommer.

Metotreksat, ciklosporin og takrolimus er andre immunsuppressive medikamenter som brukes noe ved myasthenia gravis $(1-3$, 18). Intravenøst immunglobulin brukes først og fremst som akuttbehandling, men noen få pasienter får gjentatte infusjoner for å oppnå en vedvarende effekt. Det forventes at nye monoklonale antistoffer med selektiv effekt i immunsystemet vil bli forsøkt i økende grad (3). Antistoffer rettet mot komplement og cytokiner vil kunne påvirke myasthenia gravis, og også målrettede B- lymfocytt- og T-lymfocyttantistoffer. I tillegg til effekt og mulige bivirkninger vil kostnad-nyttebetraktninger være relevante.

\section{Tymektomi}

Påvist tymom skal fjernes operativt på grunn av faren for lokal invasiv vekst. Tymektomi kan gi bedring av den myastene svakheten hos pasienter med generaliserte symptomer og acetylkolinreseptorantistoffer, særlig gjelder det pasienter med debut før 50 års alder. Tymektomi anbefales derfor til slike pasienter med generalisert sykdom og sykdomsstart før 50 år $(1-3,18,23)$, men kan også vurderes hos dem med debut i alderen 50-65 år.
Holdepunkter for thymushyperplasi og fravær av antistoffer mot titin trekker i retning av tymektomi.

Myasthenia gravis med tymom representerer en paraneoplastisk tilstand (24). Tymomer kan vokse invasivt, men fjernmetastaserer ikke. Perikard, store kar og diafragma er utsatt. Prognosen er knyttet til utviklingen av tymomet, og oppfølgingen skal være både nevrologisk og onkologisk. Ny forverring av muskelsvakheten kan indikere residiv av et tymom. CT- eller MR-undersøkelse må da utføres.

Det er ikke holdepunkter for terapeutisk effekt av tymektomi ved okulær myasthenia gravis eller ved myasthenia gravis med MuSK- eller LRP4-antistoffer. Tymektomi utføres vanligvis heller ikke ved myasthenia gravis uten påviste antistoffer. Noen av disse pasientene har imidlertid lavaffinitetsantistoffer mot acetylkolinereseptor som ikke kan påvises ved rutinetesting.

Tymektomi skal utføres tidlig i sykdomsforløpet. I økende grad benyttes torakoskopiske teknikker (25). Inngrepet tåles vanligvis godt, men vi anbefaler forutgående behandling med intravenøst immunglobulin eller plasmautskiftning hos dem med moderate eller alvorlige symptomer for å sikre optimal muskelfunksjon i postoperativ fase. Den positive effekten av inngrepet kommer gradvis over mange måneder. Gode kontrollerte studier mangler, men dokumentasjonen for tymektomi anses som overbevisende. Det er avgjørende for resultatet at alt thy-

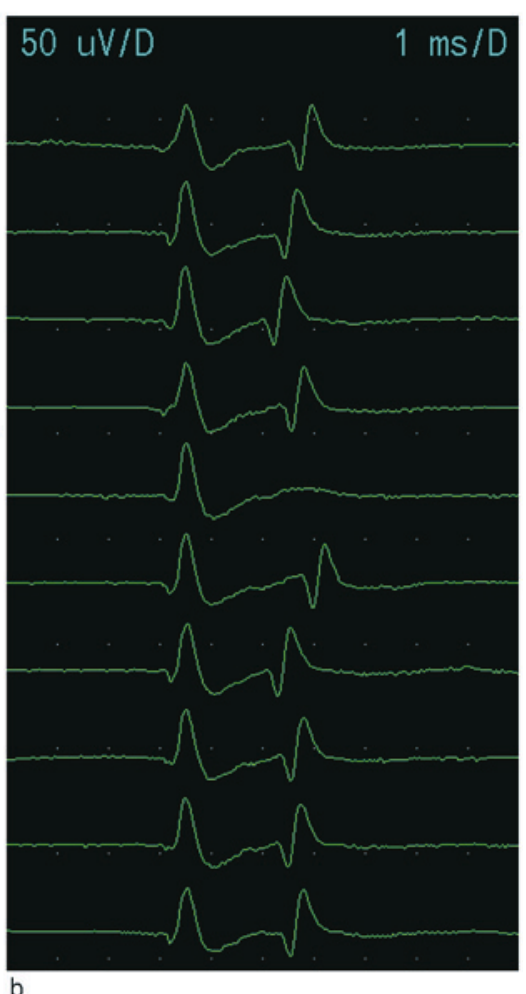

musvev fjernes, også det som kan ligge spredt i mediastinalt fettvev.

\section{Akuttbehandling}

Ved markert forverring av myasthenia gravis er det viktig med effektiv behandling som virker raskt $(1-3,18)$. Dette gjelder særlig ved truende respirasjonssvikt. Tidlig respirasjonsstøtte er da aller viktigst. Intravenøst immunglobulin og plasmautskiftning har omtrent lik effekt $(26,27)$. Begge behandlinger gir markert bedring i muskelstyrke i løpet av 2-6 dager hos $80 \%$ av pasientene. Effekten varer i 2-3 måneder. Behandlingen kombineres gjerne med intensivering, eventuelt igangsetting, av annen immunsuppressiv terapi. Hos de $20 \%$ som ikke har tilstrekkelig effekt, skal behandlingen gjentas, eventuelt kan man skifte fra den ene til den andre av de to alternativene. Intravenøst immunglobulin er noe enklere å administrere og har noe sjeldnere alvorlige bivirkninger enn plasmautskiftning, og slik behandling er dermed førstevalg ved de fleste sykehus i Norge.

Respirasjonsstøttende behandling er livreddende ved myasten krise. Ved truende respirasjonssvikt skal pasienter behandles ved intensivenhet. Terskelen for sykehusinnleggelse for pasienter med myasten forverring skal være lav på grunn av risikoen for respirasjonssvikt. Slik svikt kan inntre raskt. Doseøkning av symptomatisk medikamentell behandling er sjelden tilstrekkelig ved truende respirasjonssvikt. Når pasienten 
får respiratorbehandling, nedsettes gjerne dosen av acetylkolinesterasehemmer forbigående for å redusere slimsekresjonen i luftveiene. Før respiratorbehandlingen avsluttes gjeninnføres medikamenteringen i optimal dose.

Ved myasten krise er det viktig å behandle utløsende eller tilgrunnliggende årsaker effektivt. Ofte er dette en infeksjon, hyppigst i luftveiene.

\section{Støttebehandling}

Pasienter med myasthenia gravis har nytte av fysisk aktivitet og godt tilpasset trening. Infeksjoner skal behandles tidlig og effektivt. Overvekt er uheldig, og røyking frarådes sterkt på grunn av luftveispåvirkningen. Noen få medikamenter virker negativt ved myasthenia gravis, først og fremst anestesiologiske medikamenter som hemmer nevromuskulær transmisjon, dernest enkelte antibiotika.

Komorbiditet påvirker gjerne tilstanden. Det er viktig å behandle dette effektivt. Bivirkning av medikamenter brukt for myasthenia gravis skal man forsøke å motvirke. Særlig viktig er det å forebygge osteoporose ved langvarig behandling med prednisolon. Dette kan gjøres ved fysisk aktivitet, høyt inntak av kalsium og vitamin $\mathrm{D}$, gjerne med ekstra tilskudd, og eventuelt ved forebyggende medikamenter. For stabilt dobbeltsyn og ptose kan operativ behandling, eller eventuelt prismer, være til hjelp. Tildekking av det ene øyet fjerner dobbeltsynet.

\section{Prognose}

Pasienter med myasthenia gravis skal behandles så effektivt at de blir symptomfrie eller bare har lette til moderate symptomer. De aller fleste oppnår nær full praktisk funksjonsevne, men med en viss hemning når det gjelder tyngre fysiske oppgaver.

Dobbeltsyn, ofte intermitterende, kan bestå. Forventet livslengde er den samme med og uten myasthenia gravis (9).

\section{Svangerskap og fødsel}

Når det gjelder svangerskap, er myasthenia gravis intet hinder $(28,29) .10-15 \%$ av de nyfødte får forbigående neonatal myasteni som følge av transplacental overføring av mors IgG-antistoffer. Tilstanden er godartet og går over i løpet av få dager til noen uker, men kan interferere med suging, svelging og respirasjon i en slik grad at fødselen skal finne sted ved sykehus der man har erfaring med respiratorbehandling av nyfødte.

Behandling med pyriodistigmin, prednisolon og azatioprin i svangerskapet representerer ingen vesentlig risiko og bør fortsettes om det er behov. Mykofenolat og metotreksat er kontraindisert under graviditet og dermed relativt kontraindisert til kvinner i fertil alder. Artrogrypose, en medfødt tilstand med omfattende kontrakturer og kraftsvikt, har vært rapportert hos barn av mødre med myasthenia gravis og skyldes sterkt redusert intrauterin bevegelse som følge av kvinnens antistoffer. Denne komplikasjonen er svært sjelden.

Fødselen skal foregå som ellers, men det bør være litt lavere terskel for keisersnitt som følge av kvinnens sykdom med muskeltretthet. Et eventuelt keisersnitt bør helst være planlagt, også fordi generell narkose kan tolereres dårlig. Man bør oppmuntre til amming, som hos friske.

Pasienter med myasthenia gravis følges vanligvis av spesialist. Endringer i den medikamentelle behandlingen vil være spesialiststyrt. Men i vurdering og behandling av myasthenia gravis i samspill med øvrige medisinske tilstander vil primærlegen stå sentralt. Likeledes er det ofte primærlegen som foretar den første vurderingen ved akutt forverring og i behandlingen av akutte komorbide tilstander. Primærlegen vil likeledes gjerne stå for konsekvensvurderinger når det gjelder yrkesaktivitet og andre praktiske oppgaver

\section{Konklusjon}

Omkring 700 personer i Norge har myasthenia gravis $(5,6)$. Påvisning av spesifikke antistoffer sikrer diagnosen hos opp mot $80 \%$. Nevrofysiologisk undersøkelse er mindre spesifikk, men mer sensitiv. Acetylkolinesterasehemmer som symptomdempende behandling kombineres hos de fleste med immunsuppresjon. Tymektomi skal alltid overveies.

Behandlingen bestemmes ut fra subgruppe og biomarkører (antistoffer, thymuspatologi, debutalder, symptombilde), noe som sikrer en persontilpasset behandling. De aller fleste lever godt med bare lette til moderate symptomer.

\section{Nils Erik Gilhus (f. 1950)}

er spesialist i nevrologi, professor og overlege og leder av Klinisk institutt 1.

Forfatter har fylt ut ICMJE-skjemaet og oppgir følgende interessekonflikter: Han har mottatt foredragshonorar fra Octapharma, Baxter og Merck Serono.

\section{Emilia Kerty (f. 1948)}

er spesialist i øyesykdommer og nevrologi, professor og overlege.

Forfatter har fylt ut ICMJE-skjemaet og oppgir ingen interessekonflikter.

\section{Sissel Løseth (f. 1962)}

er spesialist i klinisk nevrofysiologi og nevrologi, seksjonsoverlege og førsteamanuensis. Forfatter har fylt ut ICMJE-skjemaet og oppgir ingen interessekonflikter.

\section{Åse Mygland (f. 1958)}

er spesialist i nevrologi, overlege og professor Forfatter har fylt ut ICMJE-skjemaet og oppgir ingen interessekonflikter.

\section{Chantal Tallaksen (f. 1949)}

er spesialist i nevrologi, professor og overlege. Forfatter har fylt ut ICMJE-skjemaet og oppgir ingen interessekonflikter.

\section{Litteratur}

1. Gilhus NE. Myasthenia and the neuromuscular junction. Curr Opin Neurol 2012; 25: 523-9.

2. Querol L, Illa I. Myasthenia gravis and the neuromuscular junction. Curr Opin Neurol 2013; 26: 459-65.

3. Gilhus NE, Verschuuren JJ. Myasthenia gravis: subgroup classification and therapeutic strategies. Lancet Neurol 2015: 14:1023-36.

4. Guptill JT, Sanders DB, Evoli A. Anti-MuSK antibody myasthenia gravis: clinical findings and response to treatment in two large cohorts. Muscle Nerve 2011: 44: 36-40.

5. Heldal AT, Owe JF, Gilhus NE et al. Seropositive myasthenia gravis: a nationwide epidemiologic study. Neurology 2009; 73: $150-1$

6. Andersen JB, Engeland A, Owe JF et al. Myasthenia gravis requiring pyridostigmine treatment in a national population cohort. Eur J Neurol 2010; 17: $1445-50$

7. Carr AS, Cardwell CR, McCarron PO et al. A systematic review of population based epidemiological studies in Myasthenia Gravis. BMC Neurol 2010 10: 46

8. Liew WKM, Kang PB. Update on juvenile myasthenia gravis. Curr Opin Pediatr 2013; 25: 694-700.

9. Owe JF, Daltveit AK, Gilhus NE. Causes of death among patients with myasthenia gravis in Norway between 1951 and 2001. J Neurol Neurosurg Psychiatry 2006; 77: 203-7

10. Kerty E, Elsais A, Argov Z et al. EFNS/ENS Guidelines for the treatment of ocular myasthenia. Eur J Neurol 2014; 21: 687-93.

11. Chiou-Tan FY, Gilchrist JM. Repetitive nerve stimulation and single-fiber electromyography in the evaluation of patients with suspected myasthenia gravis or Lambert-Eaton myasthenic syndrome: Review of recent literature. Muscle Nerve 2015; 52: $455-62$

12. Romi F, Skeie GO, Gilhus NE et al. Striational antibodies in myasthenia gravis: reactivity and possible clinical significance. Arch Neurol 2005; 62 : 442-6.

13. Gilhus NE, Nacu A, Andersen JB et al. Myasthenia gravis and risks for comorbidity. Eur J Neurol 2015: 22: 17-23.

14. Heldal AT, Eide GE, Romi F et al. Repeated acetylcholine receptor antibody-concentrations and association to clinical myasthenia gravis development. PLoS One 2014: 9: e114060.

15. Klein R, Marx A, Ströbel $P$ et al. Autoimmune associations and autoantibody screening show focused recognition in patient subgroups with generalized myasthenia gravis. Hum Immunol 2013; 74: 1184-93.

16. Maniaol AH, Elsais A, Lorentzen ÅR et al. Late onset myasthenia gravis is associated with HLA DRB1*15: 01 in the Norwegian population. PLoS One 2012; 7: e36603.

17. Zisimopoulou P. Brenner T. Trakas N et al. Serological diagnostics in myasthenia gravis based on novel assays and recently identified antigens. Autoimmun Rev 2013; 12: 924-30.

18. Skeie GO, Apostolski S. Evoli A et al; European Federation of Neurological Societies. Guidelines for treatment of autoimmune neuromuscular transmission disorders. Eur J Neurol 2010; 17 $893-902$. 
19. Pedersen EG, Pottegård A, Hallas J et al. Use of azathioprine for non-thymoma myasthenia and risk of cancer: a nationwide case-control study in Denmark. Eur J Neurol 2013; 20: 942-8.

20. Sanders DB, Hart IK, Mantegazza R et al. An inter national, phase III, randomized trial of mycophenolate mofetil in myasthenia gravis. Neurology 2008; 71: 400-6.

21. Keung B, Robeson KR, DiCapua DB et al. Longterm benefit of rituximab in MuSK autoantibody myasthenia gravis patients. J Neurol Neurosurg Psychiatry 2013; 84: 1407-9.

22. Iorio R, Damato V, Alboini PE et al. Efficacy and safety of rituximab for myasthenia gravis: a systematic review and meta-analysis. J Neurol 2015. 262: 1115-9.

23. Cea G, Benatar M, Verdugo RJ et al. Thymectomy for non-thymomatous myasthenia gravis. (review) Cochrane Database Syst Rev 2013; 10: CD008111.

24. Marx A, Pfister F, Schalke B et al. The different roles of the thymus in the pathogenesis of the various myasthenia gravis subtypes. Autoimmun Rev 2013; 12: 875-84.

25. Ye B, Tantai JC, Li W et al. Video-assisted thoracoscopic surgery versus robotic-assisted thoracoscopic surgery in the surgical treatment of Masaoka stage I thymoma. World J Surg Oncol 2013; 11: 157-62.

26. Barth D, Nabavi Nouri M, Ng E et al. Comparison of IVIg and PLEX in patients with myasthenia gravis. Neurology 2011; 76: 2017-23.

27. Gajdos P. Chevret S, Toyka KV. Intravenous immunoglobulin for myasthenia gravis. (review). Cochrane Database Syst Rev 2012; 12: CD002277.

28. Hoff JM, Daltveit AK, Gilhus NE. Myasthenia gravis in pregnancy and birth: identifying risk factors, optimising care. Eur J Neurol 2007; 14: 38-43.

29. Norwood F, Dhanjal M, Hill M et al. Myasthenia in pregnancy: best practice guidelines from a U.K. multispecialty working group. J Neurol Neurosurg Psychiatry 2014; 85: 538-43.

Mottatt 27.11. 2015, første revisjon innsendt 13.4. 2016, godkjent 30.5. 2016. Redaktør: Elena Aandstad. 